\title{
Imagining Sociology of Education Otherwise
}

\section{Keita Takayama}

\section{West as method}

I am an oversea Japanese scholar trained in North America and currently affiliated with an Australian university. Most of my scholarship has appeared in the English-language scholarly outlets in sociology of education, education policy and comparative education. In my writings, I have always attempted to challenge, or at least to raise serious questions about, the virtually unidirectional flow of intellectual influence whereby non-English-speaking education scholarship remains at the receiving end of scholarly knowledge generated in Anglo-European scholarly communities.

Among many disciplines of education scholarship in Japan, this problem of uneven intellectual influence manifests most acutely in the sociology of education. This has to do with the highly Eurocentric history of the development of sociology as a discipline and its branch, sociology of education. The recent critique of the Eurocentric foundational knowledge of sociology and the attempt to recognize global 'origins' and histories of the field (see Connell 2007; Patel 2014) has made some inroad into the reconstitution of the disciplinary knowledge. And yet, its impact in the field of sociology of education has been thus far almost negligible. International Studies in Sociology of Education, for which I currently serve as one of the editorial board members, has recently begun to acknowledge this problem, and yet much more work remains to be done in order to align the field with its parent discipline, sociology, where more impressive effort toward global sociology

School of Education, University of New England 
has been pursued via the International Sociological Association (see Bhambra 2014; Patel 2014).

Reflecting this trend in sociology of education as a whole, Japanese sociologists of education remain deeply caught up in the tradition of West as method. They are keen to 'import' theoretical work produced elsewhere and integrate it as part of their conceptual frameworks through which to make sense of empirical realities of Japanese education. While some engage in rather unreflective borrowing of such constructs, others let Japanese data speak back to the assumed universality of theories, resulting in additional categories that better explain the particular situation of Japanese education. While some of these critical theoretical engagements are noteworthy (see Takayama 2017), the fact that most of Japanese scholars do not publish their studies in English severely limits the scholarly contribution that they could make to the wider scholarly field. Cognizant of this problem, I have taken it upon myself to serve as the 'bridge,' putting the insights of Japanese education scholars in conversation with the sociology of education scholarship generated primarily in the Anglo-European countries (see e.g. Takayama 2013, 2015). This bridging work does pose a set of challenges and contradictions that trouble me from time to time (see Takayama 2011, 2016a. 2016b), and thinking through these issues has become part of my methodological reflexivity.

Elsewhere, I have attempted to analyse the problem raised here, drawing on the conceptual tools offered by a Taiwanese cultural studies scholar, Kuan-Hsing Chen (see Takayama 2016a). In his problematization of how social science knowledge has been generated in East Asia, Chen (2010) coins the term 'West as method' to refer to the way East Asian social and education researchers study their local and national contexts through the theoretical lens generated in the West. This incessant comparison of Asian realities versus Western theories, maintains Chen, has not only resulted in an inaccurate understanding of Asian self and locality, but more problematically it has rendered dormant more useful ways of understanding in East Asia that are grounded in its historical specificities. Raewyn Connell (2007) identifies this as a common problem shared among sociologists in developing countries, where their sociological methods and theories, imported 
from elsewhere, are artificially disconnected from the empirical data and political and institutional actualities. Perhaps, the problem among Japanese sociologists of education is not as severe as in 'third world' sociologists, but the same epistemological drift might be part of the problem confronted by Japanese sociologists of education.

Indeed, sociologists of education in Japan have long practiced the 'West as method.' There are many examples that I can provide here, but just to name one illustrative case; when one of the leading sociologists of education in Japan, Kokichi Shimizu (2010), articulates the particular social, institutional role of Japanese schooling as homogenizing, what he recognizes 'the uniquely Japanese' feature is constituted through a binary comparison with what he considers that of the Western schooling, differentiating. He explains that while the primary function of Anglo-American schools is to screen children on the basis of their merits and channel them into differentiated life trajectories, the Japanese schools are more focused on homogenizing children as Japanese nationals with a shared set of values and dispositions (e.g., work ethics) (p. 44-45). Similarly, drawing on the same dualistic comparison, Shimizu (2010, p. 140) articulates the "unique features" of meritocracy in Japanese schooling, through explicit comparison with those in British and American education systems.

In a sense, Japanese sociologists of education like Shimizu practice what Shozan Shibano, Joji Kikuchi and Yo Takeuchi (1992, p. 13, 22) call for more than two decade ago in a widely used sociology of education textbook; Japanese sociologists must develop comprehensive understanding of Western theoretical work as a first step towards developing original theories suited for the empirical realities of Japanese education. In this process of familiarizing oneself with Western theoretical literature, the process that their highly Eurocentric textbook aims to facilitate, however, they argued that Japanese scholars appreciate "a sense of dissonance" (違和感) between the theories generated out of a particular social context of Western countries and the empirical realities of Japan (p. 13). Shimizu's articulation of the unique institutional features of Japanese education can be viewed as an outcome of what they called for, the acknowledgement of the dissonance as a way to develop conceptual language that speaks more directly to the specific in- 
stitutional features of Japanese education.

The particular articulation of Japanese uniqueness-always via a binary contrasting with what is putatively understood as Western-is problematic, however. What underpins it is the very binary logic of coloniality that Edward Said problematized in the landmark publication, Orientalism (Said 1978). As Naoki Sakai (1997) suggests, the articulation of Eastern particularism is in a complicit relationship with Western universalism; it reifies the very colonial construct-the essential difference between Eastern (Japanese) particularity and Western universality-as the ontological fixity. No doubt that many, otherwise exceptional scholarships of education have been produced by Japanese sociologists, including Shimizu, and yet a large majority of them continue to engage in the same binary discursive practice, reinforcing the tradition of West as method (see Takayama 2016a).

Largely overlooked here is that the 'uniquely Japanese' features of schooling thus uncovered are nothing but a particular discursive construction of Japanese self, premised upon the comparative dualism of things Japanese and Western. This suggests that the supposedly 'uniquely Japanese' pedagogical and institutional features are not distinctively Japanese at all when the point of comparative reference shifts. That is, while these studies certainly 'make Japanese schooling more understandable to Anglo-American readers, whether they help, say, Brazilians and Pakistanis to understand Japanese schooling is totally a different question (see Takayama 2011). The unique Japanese features would only make sense to Brazilian and Pakistani researchers, had they been familiar with-and accustomed to understanding their own education through-the same set of conceptual lens imported from the West. Certainly this is not a farfetched proposition at all given that the global circulation of the Anglo-American scholarship has rendered it the common basis upon which other scholars in peripheral locations can meet and engage in mutual understanding (Chen 2010). And yet, this could potentially severe any attempt to produce sociological knowledge where Western experience and knowledge are adequately decentered, treated only as one of many reference points.

To pre-empt any misunderstanding of my problematization here, let me be 
clear that this is not a rejection of comparison as a form of sociological methodology. No doubt in my mind that national comparison is a legitimate methodology of social science research, because it allows us to denaturalize what is accepted within a nation state as the 'norm.' Indeed, this is the implicit intention underpinning much of Japanese sociologists' attempt to look at Japanese education through Western theoretical eyes, whether the comparison is explicit or implicit. However, the point is that when a particular kind of comparison is practiced over and over again and done unreflectively, it normalizes its geographic and epistemic point of comparison and consequently reifies the particular construction of self and other as an ahistorical and a-relational ontology. It erases the possibility of imagining Japanese education otherwise, the possibility of understanding of self through a different point of reference beyond what is putatively understood as the West.

But this is not an entirely new insight for some of the Japanese education scholars-if not sociologists - who remain highly sensitive about the symbolic violence generated through the repetitive practice of binary comparison of Western other and Japanese self. The idea of ‘tripod comparison' (三角測量) was proposed several decades ago by Japanese anthropologist/area studies specialist Junzo Kawada, and the idea has been adopted as the hallmark methodological approach in some corners of Japanese comparative education scholarship (Sugimura 2010). The idea is to use the third point of reference in order to destabilize the reification of the difference generated out of the binary comparison. Indeed, area studies comparative education scholars in Japan, many of whom specialize in education of developing countries of Asia, demonstrate extreme caution about the use of Western theoretical constructs in understanding education and society in developing countries (see Takayama 2015; Takayama in press a). In this sense, the source of critical insights has always existed in Japanese education scholarship, if not in the branch of sociology of education. Leading Japanese sociologist of education Takehiko Kariya’s (2002) notion of multiple perspectives（複眼思考法）echoes with Kawada's idea, though I have elsewhere questioned whether or not Kariya himself has attempted to move beyond the dualistic comparison of Japanese data with Anglo-American theory (see Takayama 2016). 


\section{Asia as method}

In fact, other Asian scholars, though not in education, have long recognized the similar critical insights generated by Japanese intellectuals in order to imagine the production of social science knowledge differently. Chen (2010) is one such scholar who in his influential Asia as Method proposes a way out of the problem of West as method. To imagine a different way of producing social and educational knowledge that is more useful and relevant, Chen proposes the notion of 'Asia as method,' taking cues from Yoshimi Takeuchi and Yuzo Mizoguchi. Here, Chen proposes Asia as an imaginary anchoring point where researchers, based in different parts of the geographical space known as Asia, begin to see each other as a source of knowledge. It is a way of decentering the West as a single source of theoretical knowledge and shifting the point of reference to Asia in the production of sociological knowledge. As Chen argues, perhaps more useful and relevant knowledge is generated among those who share similar historical experiences and cultural contexts in East Asia, and Asia can serve as an imaginary space where Asian scholars exchange each other's notes in developing their understanding of self and locality, or what he calls "inter-referencing mode of analysis" (250).

Such a call for regional dialogue in sociology of education has already begun. The recent special number of International Studies in Sociology of Education, titled Globalization, Changing Demographics, and Educational Challenges in East Asia, edited by Emily Hannum, Hyunjoon Park and Yuko Goto-Butler (2010) is one such example. I agree with them that a regional perspective is much needed in East Asia where there exist "little cross-fertilization among scholars of education working in different East Asian nations and little research cataloguing commonalities and disparities in educational policies and outcomes" (p. 2). Elsewhere, I have attempted to push this agenda of East Asian dialogue a step further by actually showing how the regional perspective is fundamental part of understanding the emerging inequality challenges faced by East Asia education systems (Takayama in press b). More East Asian dialogue is needed to work out effective strategies to manage the policy challenges of equity and excellence, particularly 
when systemic changes have created (or are about to create) similar equity problems in education across the region. To conclude, I hope this short essay will encourage major rethinking of the foundational knowledge of the field and of the way in which Japanese sociologists of education have long gone about producing sociological knowledge in education.

\section{References}

\section{English:}

Chen, K. (2010) Asia as method: Toward de-imperialization. Durham, NC: Duke University Press.

Connell, R. (2007). Southern theory. Crows Nest: Allen \& Unwin.

Hannum, E. Park, H. and Goto-Butler Y. (2010) Editors' introduction: Emerging issues for educational research in East Asia. In E. Hanuum, H. Park and Y. Goto-Butler (Eds) Globalization, changing demographics, and educational challenges in East Asia. Research in Sociology (pp. 1-14). Bingley, UK: Emerald Books.

Patel, S. (2014) Afterword: Doing global sociology: Issues, problems and challenges. Current Sociology 62( 4 ): 603-613.

Sakai, N. (1997) Translation and subjectivity: On 'Japan' and cultural nationalism. Minneapolis: University of Minnesota Press.

Said, E. (1978) Orientalism. New York: Pantheon Books.

Takayama, K. (in press a) Towards a new articulation of comparative educationS: Cross-culturalising research imaginations. Comparative Education.

Takayama, K. (in press b) Towards East Asian dialogue: Thinking through the policy contradictions of equity and excellence in East Asian education. In T. S. See, K. Poon and M. Manzon (eds) Equity in Excellence: Experiences of Asian High Performing Education System. Singapore: Springer.

Takayama, K. (2016a) Beyond 'the West as method': Repositioning the Japanese education research communities in/against the global structure of academic knowledge. Japanese Educational Research Association Educational Studies in Japan: International Yearbook 10: 19-31.

Takayama, K. (2016b) Deploying the post-colonial predicaments of researching 
on/with 'Asia' in education: A standpoint from a rich peripheral country. Discourse: Studies in the Cultural Politics of Education 37( 1): 70-88.

Takayama, K. (2015) Provincializing and globalizing the World Culture theory debate: Critical insights from a margin. Globalisation, Societies and Education 13( 1 ): 34-57.

Takayama, K. (2013) OECD, 'key competencies' and the new challenges of educationalinequality. Journal of Curriculum Studies 45( 1 ): 67-80.

Takayama, K. (2011) A comparativist's predicaments of writing about 'other' education: A self-reflective, critical review of studies of Japanese education. Comparative Education 47( 4 ): 449-470.

\section{Japanese:}

苅谷剛彦（2002）『知的複眼思考法：誰でも持っている創造力のスイッチ』講談社。 柴野昌山・菊池城司・竹内洋（1992）『教育社会学』有斐閣。

志水宏吉（2010）『学校にできること：一人称の教育社会学』角川学芸出版。 杉村美紀（2011）「日本における比較教育研究の方法論を巡る議論」マーク・ブレ

イ, ボブ・アダムソン, マーク・メイソン編『比較教育研究：何をどう比較す るか』上智大学出版。

高山敬太 (2017) 「「日本」版批判的教育学・教育研究を創出する一批判的知の脱西 洋化に向けて」『批判的教育学事典』明石書店。 